\title{
Beginner Voter Experience in Finding Information Through Mass Media and Social Media in the 2019 Presidential Election (Phenomenology Study of High School Students in Serang City, Banten)
}

\author{
Damayanti Masduki, Yuliani Widianingsih, Hermina Simanihuruk \\ Communication Science/Social and Political Sciences Faculty, \\ Pembangunan Nasional Veteran Jakarta University, Indonesia \\ damayanti@upnvj.ac.id,yuliani.widianingsih@upnvj.ac.id,hermina.simanihuruki@upnvj.ac.id
}

\begin{abstract}
Abstact. The purpose of this study is to find out and understand the meaning of the 2019 presidential election for Beginner Voters, illustrate how Beginner Voter seek information through mass media and social media, and describe what messages are able to make Beginner Voters determine their choices in the last 2019 Presidential Election. This study uses a qualitative phenomenological approach considering the main focus of this research is the meaning of the subject's experience. Data collection is done by in-depth interview method. The technique of determining the subject of research was carried out using purposive sampling, where respondents were selected with specific considerations and objectives namely Beginner Voters 17 years and over. Subjects were obtained by six high school students in Serang, Banten. The results showed the meaning of the presidential election was the first experience that did not want to be missed, the moment of determining the fate of the nation, awareness, care, influence and no effect on the future. In the search for information there were different activities, namely informants who were actively discussing and informants who were not actively discussing. Environmental factors were related to the involvement of Beginner Voters in selecting presidential candidates. Whether discussing or not discussing with students 'parents/guardians, Beginner Voters have the same choices as students' parents/guardians. The process of finding information on issues in the 2019 Presidential Election namely: Prices of basic needs, Employment, Foreign Workers, Religion, Presidential Candidates, Hoaxes and Sports. Environmental barriers occur for informants who cannot participate because she has not been invited to vote, while personal barriers occur for informants who do not care and do not want to seek information about the 2019 Presidential Election.
\end{abstract}

Keywords: mass media, social media, Beginner Voters, information seeking, experiences

\section{INTRODUCTION}

Various studies have found that there are several factors that cause adolescents, in this case Beginner Voters are reluctant to participate in politics. One of them is a study conducted by Henn, Weinstein, and Forrest (Limilia \& Ariadne, 2018). Research Hen, et al (2005) suggests, teenagers do not have an interest in politics and adolescents argue that politicians and parties cannot answer the nation's problems. The research shows that there are negative perceptions of adolescents participating in elections. Other studies by Pirie and Worcester (2000) lack of political participation in adolescents because there are no benefits for adolescents, adolescents do not benefit from participating. This results in teenagers being reluctant to participate in politics. Meanwhile, another thing that causes the factor of low participation of adolescents in their participation in elections is due to individualistic teenage attitudes, besides there is no benefit for them (Tamanna, 2018). 
In the presidential election of the Republic of Indonesia which was held on April 17, 2019 , the two camps tried to gain voters from teenagers by taking the niche of millennials. Unmitigated they deliberately included a program to get the voices of these teenagers. The change of agent was prepared by both of them to influence quite a lot of votes, the Ministry of Home Affairs (Kemendagri) noted that there were at least 5,035,887 Beginner Voters in the 2019 elections. These data were included in the Election Potential Population Register (DP4). /news.detik.com).

To attract the votes of the Beginner Voters who are indeed active in using social media, a party which calls itself a party of young people who supports one of the presidential candidate pairs in the 2019 election was formed. the party that carries the political concerns of the young people, qualified as the party participating in the 2019 election.

Beginner voters are a pretty sexy struggle, because these people are internet media users who are easily reached to influence both through online media and internet-based social media. According to Halolo, Rembang and Waleleng (2016) research, the Beginner Voters are actively using new media (online media and social media). About $65.21 \%$ of the Beginner Voters in the 2016 Manado Mayor and Deputy Mayor Election chose candidates who were active in providing political information through social media.

\section{LITERATURE REVIEW OR RESEARCH BACKGROUND}

In brief the theoretical basis used will focus on several concepts outlined in the following mindset:

a. Mass Media As A Source Of Information

The term mass media comes from English mass media which means communication using facilities or equipment that can reach the maximum mass and the broadest area. McQuail (2011) states that mass media is a source of power of control, management and innovation tools in society that can be utilized as a substitute for power or other resources. in other words, the media can also be the dominant source consumed by society to obtain images and images of social reality both individually and collectively, where the media presents normative values and judgments blended with news and entertainment.

One of the functions of the mass media is to provide information (to inform). In this case, the media as a component of communication as an intermediary from the communicator to the communicant. Then the media information is a tool to collect and rearrange an information, so that it becomes useful material for recipients of information. Media information as a tool that conveys information must be right on target, so that it can be conveyed properly to the target audience, this will be beneficial for the makers and recipients of information.

Definition of information according to Rachmat (2012), information can also be interpreted as anything that reduces uncertainty and the number of possibilities in a situation. Information sourced from humans in the form of ideas, opinions in the form of attitudes, opinions, beliefs and behavior of a person. With information, humans have more value, which is to be able to know what has happened, is and will happen around their living environment.

In this study, there are several indicators for the selection of information by media users. Some indicators that make someone choose the media are:

1) Values are the things that make a benchmark about someone's good or bad in seeing things. Values are the notions a person lives about what is more important or less important, what is better or less good, and what is more true or less true.

2) Factuality, namely the fact that actually happened, not fiction. Actual and factual information arises from real events, opinions and statements. 
3) Accuracy of information refers to the ability to provide accurate estimates and have a level of agreement with the recipient. When viewed in terms of time, accuracy also means information that reaches the recipient must not be too late.

4) Truth The information produced or needed must have truth value. This means that information must be free from mistakes and not misleading for those who receive the information.

\section{b. Social media}

Social media according to Anastokeskus; De La (Ardha, 2014) is a new network and information technology utilizing a form of communication that uses interactive content, as well as interpersonal relationships created and maintained, typical social media network services, content sharing, web communities, and internet forums. At least according to Eysenbach (Ardha, 2014) there are five main features that are easy to identify: (1) social networking and social interaction, (2) participation, (3) use of different providers (eg search engines, blog spaces, etc.), (4) information disclosure, and (5) collaboration (between users and user groups).

Below is an example of social media distributing user content that can be distinguished as follows:

\begin{tabular}{cc}
\hline Social Networks & Facebook, Google+, MySpace, Linkedln, IRC \\
\hline Media products community & Youtube, Flickr, Slideshare \\
Blog services & Wordpress, Blogger, Twitter, Posterous \\
Information creation community & Wikipedia, Wikispaces \\
Link sharing services & Digg, Diigo \\
Virtual community & Habbo Hotel, Second Life
\end{tabular}

Table 1. Types of Social Media (Ardha, 2014)

\section{c. Beginner Voter}

The definition of Beginner Voter can be found in the Law of the Republic of Indonesia Number 42/2008 Regarding the General Election of President and Vice President Article 1 point 21 which explains that those who have the right to vote in an election are Indonesian citizens who are even 17 years of age or older. The legislation listed also explains the right of citizens to elect a presidential candidate even though he is not even 17 years old but has been married, then has the right to elect a presidential candidate. Therefore for Indonesian citizens aged 17 to 21 years, it is an experience to choose for the first time or as a beginner voter. So that it can be understood that Beginner Voter is a constituent or a member of the public for the first time following a general election in accordance with applicable laws and regulations. The same is true for retired military or police officers, who are also according to the Election Law, including the category of beginner voters. This is because when they first became active in the army or police they still did not have the right to vote and be elected in elections.

Feishbein and Azjen as quoted by Littlejohn (2009) in the theory of Reasoned Action said that each individual in doing an action is based on a certain reason and belief. Therefore one's choice of behavior in general elections / presidential elections is influenced by certain attitudes and subjective norms. Both of them can simultaneously encourage the formation of Beginner Voter behavior in determining the figure who is idolized to become president. There are at least three perspectives that can be used to explain voter behavior in general voters / presidential elections. The three perspectives are sociological, psychological, and economic / rational (Asfar, 2006)

From these three perspectives, in a psychological perspective approach, political socialization received by a person greatly influences their political choices, especially when 
first determining political choices. Research results in the presidential election along with his deputy in 2014 showed that the existence of Beginner Voter behavior that was different from the elections in the previous year, mainly from the psychological aspects of Beginner Voter behavior. The study said that a person's attitude is a reflection of one's personality. Attitude is a decisive variable in the process of influencing one's political behavior. Psychological approach emphasizes three aspects as the main study, namely emotional ties in a political party, orientation to issues, and orientation to candidates. Orientation towards candidates is seen from the figure and character of a person in the general election. Personnel can be in the form of a formal position, closeness to God, intelligence, popularity, closeness to the people, and success that has been achieved. The nature of a person can be observed in his personality, for example honest, clean, tolerance developed, easy to help others, generosity, prioritizing public interests, special assessment of someone (inclusive), and patience. Whereas what is meant by issues are actual and crucial problems that need to be carefully handled and resolved by candidates.

\section{d. Information seeking}

Information comes from the Latin language that is informare which means "to form through education". In the Indonesian National Encyclopedia (2004), information is a message or information in the form of sound, signal, or light that can be received in a certain way by the target, the recipient which can be a living creature or a machine. That is, information can consist of various forms, which can be conveyed from the sender of the message to the recipient of the message. And the recipient of the message is not only living things, but also systems, such as cell phones, computers, and others.

Dervin and Nilan (Suwanto, 1997), state that information is: a) all news, b) all documents or sources, c) all data, or d) all published material. Other meanings according to Saracevic (Pendit, 2003), information is grouped into three terms:

1) Narrowly, information is a series of signals or messages needed in decision making.

2) Information in a broad sense is associated with cognitive processes and the ability to understand in humans.

3) More broadly, information is not only related to the message or process, but also its social context, in the form of situations, task studies, etc.

From the above understanding, then information is data that has been processed into a form, whether in the form of messages or information such as someone's decision, or physical objects delivered by the sender to the recipient, which is useful for the preparation of information, making conclusions, and the basis for making decisions both now and in the future.

\section{e. Information Needs}

Understanding Information Needs according to Yusup and Subekti (2010), is a condition that occurs in the structure of one's cognition that is felt to be a vacuum of information or knowledge as a result of a task or just being curious. If seen from this understanding, the meaning of Information Needs here is not limited to understanding information, but also knowledge.

Meanwhile, according to Kuhlthau in Astuti (2008), formulating Information Needs as something that gradually arises from a vague awareness about something that is missing, and in the next stage information seekers want to know and find information that will contribute to understanding and meaning.

Miranda and Tarapanof (2008), defines information needs as a situation or process that starts when someone feels there is a gap (information) between information and knowledge available to solve a problem and the actual solution of a problem. 
Other notions from Wilson (1996) citing Information Needs raised by Weigts, include:

1) The need for new information;

2) The need to explain the information obtained;

3) The need to strengthen the information obtained, and he argues that the need to add some needs because the focus of this type of need is cognitive needs, which addresses the importance of beliefs and values, and information will be needed to obtain these things: a) The need to explain existing beliefs and values; b) The need to strengthen existing beliefs and values.

Information Needs and Behavior Information relating to psychology. This can be seen in the following image:

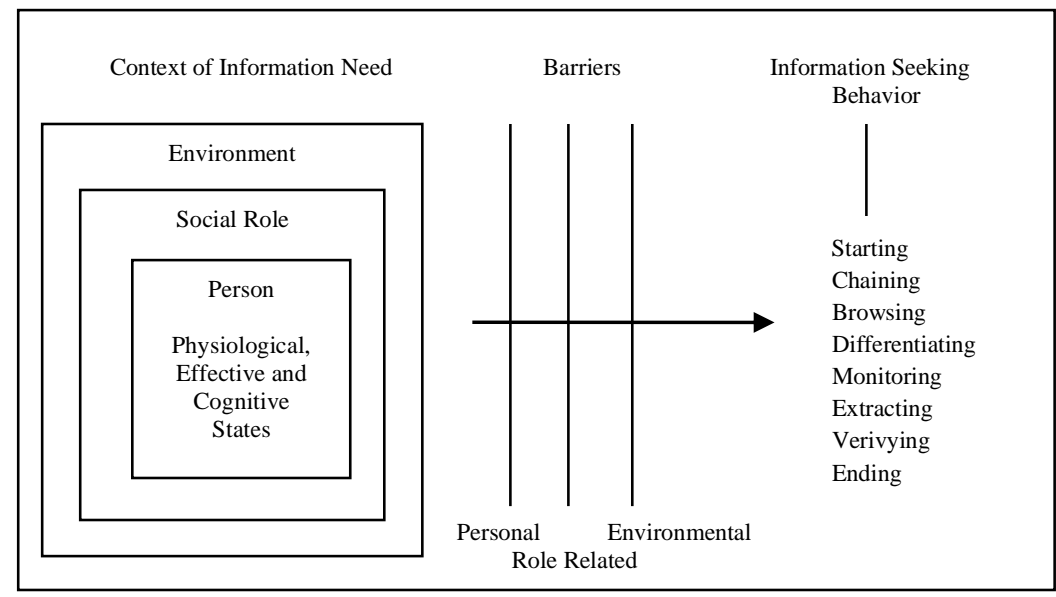

Figure 1: David-Ellis Information Discovery Behavior Model

There are several models that explain the information discovery behavior, one of which is the Ellis information behavior model where the model is located between the micro analysis of information discovery and macro analysis of information discovery as a whole. In general, Ellis (1989, and 1993 in Wilson, 1999) explains that information discovery behavior consists of several features (characteristics), namely:

1) Starting, consisting of activities that trigger information retrieval activities.

2) Chaining, activities following a series of citations, quotations or forms of reconciliation between other documents.

3) Browsing, searching, wandering but with a bit directed, in areas that are considered to have potential.

4) Differentiating, sorting, using features in the source of information as a benchmark for checking the quality of content / information.

5) Monitoring, monitoring developments by concentrating on selected sources.

6) Extracting, systematically digging in a source to retrieve material / information deemed important.

\section{METHODOLOGY}

This study uses a qualitative or naturalistic approach to natural conditions that aims to obtain deeper and more detailed research results. Data collection techniques are carried out by trangulation (combined), data analysis is inductive, and qualitative research results emphasize more meaning than generalization.

The researcher makes a complex illustration, examines words, detailed reports from the respondents' views and conducts a study of the situation experienced by Beginner Voter in their activities seeking information to determine their votes in the 2019 Presidential Election. 
The phenomenological research method aims to find out the world from the point of view of those who experience it directly and relates to the natural characteristics of human experience, and the meaning inherent in each individual. The object of study of phenomenology is an awareness of experience, a situation that provides a first-person perspective. The use of the phenomenological approach is a research activity by exploring the values in the experience and life of Beginner Voter in their activities seeking information to determine their votes in the 2019 Presidential Election.

The study was conducted in the city of Serang, Banten Province. Determination of research subjects is done by using purposive sampling, where respondents are chosen with specific considerations and goals. In accordance with the purpose of the study, the research subject was devoted to Beginner Voter, namely 17-year-old high school students from three high schools in Serang City, Banten. The number of research subjects was determined by 6 people. The amount according to researchers is sufficient according to the opinion of the Dukes (Creswell, 1998) which mentions phenomenological research using 3 to 10 subjects, with the criteria of research subjects as follows:

1) Beginner Voter is a 17-year-old high school student

2) Determine their votes on one of the candidate pairs or not use their votes in the 2019 Presidential Election.

3) Use information sources in determining their votes in the 2019 Presidential Election

Data collection techniques in this study are: in-depth interviews (in depth interviews) semi-structured (semistructure interviews), and passive observation (passive participation). Researchers come to the subject by observing the activities carried out by the subject but not involved in these activities.

Analysis of the data used in this study is based on Cresewll's (1998) theory in data analysis techniques for phenomenological research as follows:

a. First, describe the personal experience of the phenomenon being studied. The author describes experiences related to the phenomenon of research by setting aside personal experiences, so as to be able to analyze the data presented by the research subject.

b. Develop a list of important questions from the research subject then find questions derived from interview data or other data sources about how the subject experienced a topic, make a list of these important statements. This process is called horizonalizing data and furthermore the authors develop questions and conduct questions that are able to make researchers obtain information about the experience of the research subject.

c. Pay attention to important questions from the horizonalizing process and then combine these statements into meaningful units called "meaning units"

d. The author describes "what" the subject of natural research on the phenomenon. This process is called "textural description" where the writer explains the text about the experience the subject has gone through

e. Describe "how" the experience of the phenomenon experienced by the subject, called "structural description". The author describes the setting and circumstances experienced by the subject.

f. At this stage, the writer combines both textural description and structural description, this is the essence of phenomenological research experience. In this stage will be illustrated with a long paragraph that describes what the subject's experience and how the subject experienced it.

The following table analyzes data techniques in phenomenological research proposed by Creswell (1998): 


\begin{tabular}{ll}
\hline \multicolumn{1}{c}{ Data Analysis and Representation } & \multicolumn{1}{c}{ Phenomenology Research } \\
\hline Data processing & Create and organize files or notes for research data \\
Read and remember data & Read the text, make boundaries of notes, and create \\
& initial codes \\
Describe data & Describe personal experiences through epoche \\
& Describe the essence of the phenomenon \\
Data Classification & Develop important statements from the subject \\
& Develop a structural description (structural \\
& description), "how" phenomena experienced by the \\
& subject \\
Images and visualizations & Develop essence \\
& Present a narrative of the essence of experience in the \\
& form of tables, pictures, or discussions. \\
\hline
\end{tabular}

Table 2. Data analysis technique (Creswell,1998)

\section{RESULTS AND DISCUSSION}

Results of research conducted on the Beginner Voter Experience in Searching for Information Through Mass Media and Social Media in the 2019 Presidential Election (Phenomenology Study of High School Students in Serang, Banten), from July to August 2019 in SMU Negeri 1 High School, SMU Agro Taktakan High School, and SMU Informatika High School in Serang City, Banten.

The informant in this study was Beginner Voter in the 2019 Presidential Election, namely high school students in the City of Serang, Banten, who already had the right to vote. Students who become informants in this case as follows:

\begin{tabular}{llll}
\hline No. & Initial Informant & Gender & \multicolumn{1}{c}{ School } \\
\hline 1. & Ala & M & SMU Negeri 1, Serang City, Banten \\
2. & Ten & F & SMU Negeri 1, Serang City, Banten \\
3. & Mua & M & SMU Agro Taktakan, Serang City, Banten \\
4. & Res & F & SMU Agro Taktakan, Serang City, Banten \\
5. & Fur & M & SMU Informatika, Serang City, Banten \\
6. & Aul & F & SMU Informatika, Serang City, Banten \\
\hline \multicolumn{2}{r}{ Table 3. Informant Data (Processed data) }
\end{tabular}

a. Meaning of Presidential Election for Beginner Voters

The meaning of the general election for Beginnr Voter in Serang City, is the first experience that Beginner Voter does not want to miss, it is an important moment because it determines the fate of the nation five years in advance, Beginner Voter who is aware of and very concerned about the 2019 presidential election, and Beginer Voter who does not has awareness and doesn't care about the 2019 presidential election. From the 6 informants, 5 were aware of the importance of the presidential election, while 1 informant was not interested in the presidential election.

There are two meanings that the presidential election will affect the future, the first meaning is that it is very influential and wants to participate and seek information about the presidential candidates in the 2019 presidential election. Second, that the presidential election has no effect on his future and therefore he does not want to find information about the presidential candidates at the 2019 Presidential Election. From 6 informants, 5 informants stated that the 2019 Presidential Election event had a great influence on their future and 
wanted to find information about presidential candidates in the 2019 Presidential Election, while 1 informant stated that it had no effect on their future and did not want to find information about the presidential candidates in the 2019 Presidential Election.

As revealed by Ala, Ten, Mua, Res, and Fur. They even waited for the election. At school Ala and Ten often discuss and even debate with classmates when discussing presidential elections. While Res tends to be less concerned and feel the events are mediocre. Ala, Ten, Mua, and Fur used their voting rights in the 2019 Presidential Election. Meanwhile, Res wanted to use his voting rights but did not get an invitation. Res felt sad and disappointed because Res did not get an invitation to the presidential election, whereas in the previous mayor election Res received an invitation to vote. While Aul even though he voted in the 2019 Presidential Election did not really feel the event as extraordinary, actually Aul was sleeping at the time, but because he was greeted by friends, Aul participated in the 2019 presidential election.

The events of the 2019 presidential election were interpreted by Beginner Voter in the City of Serang Banten as an important moment and should not be missed, because it determines the fate of the nation five years ahead according to Ala, Ten, Mua, Res, and Fur. But according to Aul, the meaning of the 2019 presidential election does not really affect Aul future. So Aul did not try to find out about the incident and tends to be indifferent to the presidential election event.

\section{b. Information Seeking}

In the search for information, there are different activities between the six informants, first, the informant who is active in discussions with parents, friends, and organizations. Second, informants who are not actively discussing. There were 4 informants who actively discussed well with parents, friends and organizations. Whereas 2 informants did not actively discuss both with parents, friends and with their organizations.

Two informants who were not actively discussing, Fur and Aul. Fur because Fur doesn't have parents, but Fur has a brother who pays for his school. However, Fur did not discuss with brother, because he was busy working. While Aul, despite having both parents, did not discuss it with her parents about the 2019 presidential election.

Although discussing with both parents, and admiring the siblings who sent them to school, the five informants claimed that they did not necessarily have to have the same votes as both the parents and the brother who sent them to school. Ten even admitted that at first he was different from the choices of his parents, until finally he decided to switch choices because the presidential candidate he was about to elect, exploited religion. While both Ala, Mua and Res, stated that their choices did not have to be the same as their parents, but in the end they knew that they had the same choice. Although Fur's school was funded by Fur's older brother, Fur admitted that his choice did not have to be the same as brother's. According to Fur even though he never discussed the 2019 presidential election, Fur was sure that his brother gave Fur freedom to choose and would not force him to follow his brother's choice. While Aul, who was not actively discussing with parents, made the same choices as her parents, because she had to choose and did not know who to choose, while Aul at that time preferred to rest at home but was forced by friends to vote.

In searching for information, both Ala, Ten, Mua, Res, and Fur need information related to the 2019 Presidential Election because they want to participate and do not want to be wrong in choosing a leader in the next five years. While Aul is not too concerned with the incident. Aul did not even want to know about the incident either through the television mass media and social media. Aul claimed to have never been exposed to information related to the Presidential Election. At home, Aul did not discuss with parents or her older siblings who had experience in the 2014 presidential election. In this case, Aul was very different from the five 
other informants who were very enthusiastic about seeking information, even discussing with family, friends in the house or at school and social media. Whatsupp, Facebook, Instagram and Twitter.

\begin{tabular}{|c|c|c|c|c|c|c|c|c|c|c|c|c|c|}
\hline \multirow[t]{2}{*}{ No. } & \multirow{2}{*}{$\begin{array}{l}\text { infor } \\
\text { mant }\end{array}$} & \multicolumn{6}{|c|}{ Mass Media } & \multicolumn{6}{|c|}{ Social Media } \\
\hline & & $\begin{array}{l}\text { Kom } \\
\text { pas } \\
\text { Tv }\end{array}$ & $\begin{array}{l}\text { Tv } \\
\text { On } \\
\text { e }\end{array}$ & $\begin{array}{l}\text { Met } \\
\text { ro } \\
\text { Tv }\end{array}$ & $\begin{array}{l}\text { Repu } \\
\text { blika } \\
\text { On } \\
\text { line }\end{array}$ & $\begin{array}{l}\text { Det } \\
\text { ik. } \\
\text { co } \\
\text { m }\end{array}$ & $\begin{array}{l}\text { Tirt } \\
\text { o. } \\
\text { co. } \\
\text { id }\end{array}$ & $\begin{array}{l}\text { Era } \\
\text { Mus } \\
\text { lim// } \\
\text { me } \\
\text { dia } \\
\text { islam }\end{array}$ & $\begin{array}{l}\text { Yo } \\
\text { utu } \\
\text { be }\end{array}$ & $\begin{array}{l}\text { Face } \\
\text { book }\end{array}$ & $\begin{array}{l}\text { Twi } \\
\text { tter }\end{array}$ & $\begin{array}{l}\text { Insta } \\
\text { gram }\end{array}$ & $\begin{array}{l}\text { Grup } \\
\text { What } \\
\text { supp }\end{array}$ \\
\hline 1 & Ala & $\checkmark$ & $\checkmark$ & - & $\checkmark$ & - & - & $\checkmark$ & $\checkmark$ & $\checkmark$ & $\checkmark$ & $\checkmark$ & $\checkmark$ \\
\hline 2 & Ten & $\checkmark$ & - & $\checkmark$ & - & $\checkmark$ & $\checkmark$ & - & $\checkmark$ & $\checkmark$ & $\checkmark$ & $\checkmark$ & $\checkmark$ \\
\hline 3 & Mua & $\checkmark$ & $\checkmark$ & - & $\checkmark$ & - & - & $\checkmark$ & $\checkmark$ & $\checkmark$ & $\checkmark$ & $\checkmark$ & $\checkmark$ \\
\hline 4 & Res & $\checkmark$ & $\checkmark$ & - & $\checkmark$ & - & - & $\checkmark$ & $\checkmark$ & $\checkmark$ & $\checkmark$ & $\checkmark$ & $\checkmark$ \\
\hline 5 & Fur & $\checkmark$ & $\checkmark$ & & $\checkmark$ & - & - & $\checkmark$ & $\checkmark$ & $\checkmark$ & $\checkmark$ & $\checkmark$ & $\checkmark$ \\
\hline 6 & Aul & - & - & - & - & - & - & - & - & - & - & - & - \\
\hline
\end{tabular}

Both Ala, Ten, Mua, Res, and Fur admit that their choices are no different from their parents and older brothers. Ala whose parents are cadres of a party supporting one of the presidential candidates claimed to find out about the two presidential candidates through the mass media television, Kompas Tv and TV one, Republika.co.id online media, Kompas.com, and several other media such as Muslim Era, youtube, Facebook, twitter, instagram, and whatsupp groups, thus making a choice on one particular candidate.

Likewise with Ten who claimed to choose through the process of finding information from parents, friends and mass media such as Metro Tv and Kompas Tv, Detik.com, Tirto.co.id, did not like the Indonesian Lawyer Club program on Tv One, because it tends to corner wrong one candidate and colleague, also find some information on social media facebook, youtube, instagram, twitter and whatsupp group.

Mua acknowledged that even though his choices were the same as his parents, Mua conducted information searches through the environment and his school friends as well as the Tv One, Kompas Tv, Republika.co.id and online social media such as Era Muslim, youtube, Instagram, twitter and whatsupp Groups.

Likewise, Res is looking for information through the mass media Tv One, Kompas Tv, Republika.co.id, and social media youtube, facebook, instagram, twitter, and whatsupp group. Although finally Res could not give her vote because she did not get an invitation.

In line with the others, Fur admitted that his choice fell on one of the candidates by going through the process of finding information both through discussions with both parents and looking for it through the mass media Tv One, Kompas Tv, Republika.co.id, Kompas Tv, and social media youtube, instagram, facebook, twitter, and whatsupp groups, because he doesn't want to be wrong in choosing leaders for the next five years.

While Aul is not interested in any information about the presidential election. When asked what made her interested in watching television, Aul did not know what made her interested in one thing, Aul also did not watch certain television, Aul watched the soap opera "Love Blind" when her mother watched the television show. Aul's time is spent in the room opening youtube and social media through whatsupp related to small talk such as hairstyles, Korean boy band or girl band singers.

The curiosity of the five respondents was very high and enthusiastic when telling how the process of obtaining information. Even Ala and Ten, who have different views on the choice of their presidential candidates, often argue with classmates when talking about presidential candidates. Ten, whose parents are sympathizers of one of the parties supporting 
the president of her choice, is looking for information that finally justifies her parents' choice. While Ala, who is at odds with Ten, also seeks information that finally strengthens the choice of his parents. Although Ala admitted, his parents released him to find information in accordance with his choice. After searching for information, Ala acknowledged that his choice was the same as the choice of his parents.

While Fur doesn't have parents to discuss. Fur has a brother who has a choice that turns out to be the same as Fur. Fur said he rarely discussed with his brother about the 2019 presidential election. Fur claimed to admire his brother for paying for his school, even though Fur admitted that if his choice turned out to be different from his brother, it would not be a problem, "Because my brother is a very open person, my brother will understand if my choice is different from him,".

Res and Mua claimed that their choices were the same as their parents. But they stated that they were never forced to follow their parents' choices. Res and Mua sought information related to the president who will become the leader in the next five years. Because of this, both Res and Mua sought information about their elected president. However, both Res and Mua did not deny that their choice was related to the religion they professed and followed the ulama in their environment. Both Res and Mua were active in the recitation near their home, so much of the information he received was obtained from the neighborhood. However, they claimed that they did not swallow the information they received. Mua tried to find information through television and facebook as well as whatsupp groups to confirm the information He obtained. Likewise, Res is looking for information through youtube, facebook and online media to establish her choice in the 2019 Presidential Election.

The process of finding information in the mass media and social media related to the issues submitted by the two candidates, Ala actively sought information related to presidential candidates from both camps. Ala finds and feels the prices of goods that are increasingly difficult to reach, people's lives are getting more difficult, Ala wants to find a presidential candidate who is able to control prices and improve people's lives. Another problem in Ala notes is information related to foreign workers who easily work in Indonesia. Ala wants the government to make rules regarding foreign workers so that Indonesia should use domestic workers. this is related to the later emergence of the Islamic movement 212 because of injustice towards Muslims.

Meanwhile, Ten, who is from the same school as Ala, admitted actively seeking information related to presidential candidates who were able to build and popularize, Ten discovered the existence of religious exploitation in the 212 events that made her change her choice of presidential candidates. In addition, various types of hoaxes, ranging from PKI descendants to the issue of foreign workers who according to Ten are experts / professionals who do not exist in Indonesia, not just any foreign workers. Ten also doesn't watch Indonesia Laywers Club on TV One because it tends to corner one of the candidates.

While Mua highlighted his findings related to the difficulty of finding employment, the issue of layoffs on BUMN workers, the ease with which foreign workers entered Indonesia, the arrests of Islamic clerics / leaders and various persecutions made him disappointed. Mua also found the concern of one of the candidates in his favorite sport, which is soccer

Res, as a person who came from a poor family, Res found the concern of one of the candidates for employment, and the issue of foreign workers made easier in Indonesia. Labor problems were also discovered by Fur. Fur sought information related to the two candidates' programs on employment opportunities and business opportunities. Fur also found the issue of foreign workers, especially from China who work in Indonesia without having to use Indonesian. Meanwhile, to look for information, even though the same school with Fur, Aul 
who is not interested in the issue of presidential elections, is not looking for information related to the presidential election

The following table searches information based on issues obtained from mass media and social media:

\begin{tabular}{|c|c|c|c|c|c|c|c|c|}
\hline No & Name & $\begin{array}{l}\text { Prices of } \\
\text { basic goods }\end{array}$ & $\begin{array}{l}\text { Job } \\
\text { vacancy } \\
\text { issues }\end{array}$ & $\begin{array}{l}\text { Foreign } \\
\text { workers }\end{array}$ & $\begin{array}{l}\text { Religious } \\
\text { issues }\end{array}$ & $\begin{array}{l}\text { Issues } \\
\text { related to } \\
\text { Presidential } \\
\text { Candidates }\end{array}$ & Hoax & Sports \\
\hline 1. & Ala & $\begin{array}{l}\text { Prices of } \\
\text { basic goods } \\
\text { are difficult } \\
\text { to reach }\end{array}$ & - & $\begin{array}{l}\text { Ease of } \\
\text { foreign } \\
\text { workers } \\
\text { working in } \\
\text { Indonesia }\end{array}$ & $\begin{array}{l}\text { Injustice } \\
\text { towards } \\
\text { Muslims }\end{array}$ & $\begin{array}{l}\text { Who is able } \\
\text { to control } \\
\text { prices and } \\
\text { improve } \\
\text { people's } \\
\text { lives }\end{array}$ & - & - \\
\hline 2. & Ten & - & - & - & $\begin{array}{l}\text { The } \\
\text { existence } \\
\text { of religious } \\
\text { exploitatio } \\
\mathrm{n} \text { and } \\
\text { change her } \\
\text { choices }\end{array}$ & $\begin{array}{l}\text { Able to build } \\
\text { and } \\
\text { popularize }\end{array}$ & $\begin{array}{l}\text { Issues } \\
\text { of PKI } \\
\text { descent } \\
\text { and } \\
\text { foreign } \\
\text { worker } \\
\text { s }\end{array}$ & - \\
\hline 3. & Mua & $\begin{array}{l}\text { Difficult } \\
\text { economy of } \\
\text { the } \\
\text { community }\end{array}$ & $\begin{array}{l}\text { Difficult to } \\
\text { find } \\
\text { employme } \\
\text { nt }\end{array}$ & $\begin{array}{l}\text { Layoffs } \\
\text { against } \\
\text { workers, } \\
\text { The use of } \\
\text { foreign } \\
\text { workers that } \\
\text { can be done } \\
\text { by Indonesian } \\
\text { workers }\end{array}$ & $\begin{array}{l}\text { Arrest and } \\
\text { persecutio } \\
\text { n of } \\
\text { Islamic } \\
\text { leaders/ula } \\
\text { ma }\end{array}$ & - & - & $\begin{array}{l}\text { Concern } \\
\text { for one } \\
\text { of the } \\
\text { candidate } \\
\mathrm{s} \text { for the } \\
\text { sport of } \\
\text { football }\end{array}$ \\
\hline 4. & Res & $\begin{array}{l}\text { The } \\
\text { economy is } \\
\text { getting } \\
\text { harder and } \\
\text { harder }\end{array}$ & $\begin{array}{l}\text { One } \\
\text { candidate's } \\
\text { concern for } \\
\text { employme } \\
\text { nt }\end{array}$ & $\begin{array}{l}\text { Easier foreign } \\
\text { workers in } \\
\text { Indonesia }\end{array}$ & $\begin{array}{l}\text { Many } \\
\text { ulama have } \\
\text { been } \\
\text { arrested for } \\
\text { speaking } \\
\text { out for } \\
\text { justice } \\
\text { such as } \\
\text { Ustadz } \\
\text { Tanjung }\end{array}$ & - & - & - \\
\hline 5. & Fur & - & $\begin{array}{l}\text { Job } \\
\text { opportuniti } \\
\text { es and } \\
\text { business } \\
\text { opportuniti } \\
\text { es }\end{array}$ & $\begin{array}{l}\text { Foreign } \\
\text { workers from } \\
\text { China who } \\
\text { work in } \\
\text { Indonesia } \\
\text { without using } \\
\text { Indonesian }\end{array}$ & - & - & - & - \\
\hline 6. & Aul & - & - & - & - & - & - & - \\
\hline
\end{tabular}

The process of finding information carried out by the five informants through the Starting stage, which is looking for initial references and secondary resources, namely by discussing with parents, friends and obtain information through mass media and social media. After being exposed to preliminary information, then the informants did the Chaining which is to follow the information chain by looking for good reference materials using mass media, social media, discussing with friends, and parents and the environment, then browsing through the information obtained. According to Ten, she initially chose another candidate, but 
after obtaining information from the mass media, social media, and further discussions with parents, Ten changed her vote.

Ten told that before she had different choices with her parents. "But after the 212 events, I feel that the first presidential candidate I chose, has exploited religion, so I followed my parents' choices, in fact my mother was a sympathizer of one of the supporters of the presidential party who was competing".

Likewise, Ala, Mua, Res and Fur who already have preliminary information, then do chaining by looking for information both in the mass media, social media and discussing with school friends, the home environment, and parents, who then become more convinced of their choices that are not different from both parents, as well as Fur and his brother.

The next step is to differentiate, namely differentiating sources of information and filtering information. For the five informants, they made a comparison of the information they received. Ala, Mua, Res, Fur, and Ten have mass media information and television as their references, and begin to filter information in accordance with the presidential candidates they elect. Until the Monitoring stage, which is monitoring developments that occur and continues to add information that reinforces his choice. Until then at the Extracting stage by filtering the information obtained by continuing to search for information whether the information obtained is correct, even the five informants did the extracting by giving information to friends about what they knew in accordance with the information they obtained related to their chosen presidential candidates. "Thus we will know the advantages and disadvantages of our chosen president," said Ala. Ten also noted the advantages and disadvantages of his chosen presidential candidate, by trying to explain to his friends during the discussion why his chosen presidential candidate had these shortcomings. Both Ala, Fur, Res, Mua, and Ten have reached the Ending stage, namely checking to make sure the information obtained is correct and confident in their choices.

In obtaining information, both Ala, Ten, Mua, Fur, and Res do not have significant obstacles, "except sometimes lack of quota" said Mua, as well as Fur and Res. While both Ala and Ten, whose economic level of family life is better, do not have these obstacles. The five informants did not have obstacles with matters related to rules or norms in their lives, parents and Fur's older brother.

The five informants acknowledged that both parents and fur's broter gave the informants freedom to obtain information related to their choices. The information obtained was recognized by the five informants as information that confirmed their choice. Ten and Ala, for example, strongly defended their respective elected presidential candidates, however, each acknowledged the shortcomings of his chosen presidential candidates, but neither Ten nor Ala saw these deficiencies as obstacles in themselves in determining their vote to their presidential candidates.

Regarding environmental barriers, almost none were found by Ala, Ten, Fur, and Mua. Environmental barriers in terms of access to vote, which is the obstacle of informants Res. Because Res did not get an invitation to come to the voting booth and deliver her voice to vote for her chosen presidential candidate. As for Aul, obstacles faced her, because Aul did not care about the 2019 Presidential Election.

\section{c. Message at the 2019 Presidential Election}

The message that made the Beginner voter determine their choice in the 2019 presidential election obtained from the mass media of television, according to Fur was during the presidential debate about cards, Jokowi had many cards while Prabowo had only one card that could be used for access to both health and education.

The message remembered by Ten through the mass media so that she made her choice, is the spread of hoaxes in the mass media and social media, Ten does not like the Indonesian 
Lawyers Club program on Tv One, because it tends to corner one of the 2019 presidential candidate camps.

According to Res, the most memorable message and determining her choice in the 2019 Presidential Election was the 'Rumah Siap Kerja Prabowo-Sandi' program, because according to Res after graduating from school she wanted to get a job immediately, so she really expected 'Rumah Siap Kerja Prabowo-Sandi' program.

Whereas Mua was very impressed with the message of one of the candidates who carried out the issue of sports, because Mua had a hobby of football, with the candidate siding with football, Mua hoped soccer in Indonesia could develop.

According to Ala, messages through mass media and social media made him make choices in the 2019 Presidential Election very much, one of which was the invasion of foreign workers, especially from China who came to Indonesia, the price of basic necessities is high, and the Metro TV media is too biased. Ala hopes that the media can be the voice of the hearts of the people rather than the government, because at this time the era of democracy must be a voice of the people, not the mouthpiece of the government, Ala hopes there are laws that can be upheld against unbalanced media.

Although Aul is not too concerned with the 2019 Presidential Election event, according to Aul the message she remembers from the television media regarding Jokowi is 'blusukan' while Aul does not have a message she can remember about Prabowo

\section{CONCLUSION}

The meaning of the 2019 presidential election for Beginner Voter in Serang City, is the first experience that Beginner Voter does not want to miss. The 2019 Presidential Election is interpreted by Beginner Voter in the City of Serang Banten as an important moment, because it determines the fate of the Indonesian Nation in the next five years. There are Beginner Voter who is aware the importance of and not concerned with the 2019 presidential election.

In the search for information, there are different activities between the six informants, first, the informant who is active in discussions with parents, friends, and organizations. Second, informants who are not actively discussing. The media used to obtain information consists of mass media and social media. As for the mass media consisting of Kompas Tv, Tv One, Metro Tv, Republika Online, Detikcom, and Tirto.co.id. While social media: used to obtain information is The Era Muslim, youtube, instagram, twitter, facebook, and whatsupp groups.

Environmental factors of parents or older brothers who pay for school have a significant influence in determining the involvement of Beginner Voter in participating in the 2019 presidential election. Four informants seek information and discuss with both parents and have the same choices as their parents. While 2 informants although not occupied with parents or older brothers, but the choice is the same as the choices of parents and older brothers.

The process of finding information on issues raised by presidential candidates in the 2019 Presidential Election captured by the five informants was the Price of Basic Materials, Employment, Foreign Workers, Religious Issues, Issues Related to Presidential Candidates, Hoax News, and Sports.

There are no significant obstacles for the four informants in searching for information and determining their choices in the 2019 Presidential Election. However, for Res, environmental barriers occur when Res is unable to vote at the polling place in the 2019 Presidential Election booth, this happens because Res does not get an invitation to come to the voting booth so she could not vote, and Res did not know how to retain her voting right to 
vote. In fact, in the previous mayor election Res received an invitation and was registered as a citizen who gave her right to vote. While personal barriers occurred to Aul when she did not care about the events of the 2019 Presidential Election and was not interested in finding information about the 2019 Presidential Election.

The message exposed that was able to make informants decided to vote their choice in the 2019 Presidential Election was the presidential debate about cards, one candidate had many cards while the other candidate had only one card. The other thing is the Hoax that is scattered in the media, and the Tv One Indonesia Lawyers Club program which, according to one informant, tends to corner one side. In addition, the Rumah Siap Kerja Prabowo-Sandi Program, and also message that send by one of the candidates that want to support Indonesian football. Other message that is also attached to the informant is the invasion of foreign workers, especially from China who came to Indonesia, the high of basic needs prices, and blusukan. In addition, the very bias of mass media Metro TV, informants hope there is a law that can be enforced against unbalanced media.

\section{BIODATA}

Damayanti Masduki, Yuliani Widianingsih, and Hermina Simanihuruk are a lecturer of Communication Science at Pembangunan Nasional Veteran Jakarta University, Indonesia.

\section{REFERENCES}

\section{Book}

Abadi, T. W., \& Putri, R. A. O. (2016). Media dan Perilaku Pemilih Pemula pada Pilihan Presiden Tahun 2014 di Kabupaten Sidoarjo. Journal Ilmu Komunikasi, 5 (1).

Asfar, Muhammad. (2006). Pemilu dan Perilaku Memilih. Surabaya: Pustaka Eureka

Berliani, Ardha. (2014). Social Media Sebagai Media Kampanye Partai Politik 2014 di Indonesia. Journal Visi Komunikasi. 13 (1).

Creswell, John W. (1998). Qualitative Inquiry and Research Design: Choosing. Among Five Tradition. London: Sage Publications.

Djuarsa, S. Sendjaja .(2007). Pengantar Ilmu Komunikasi. Jakarta: Universitas Terbuka.

Ensiklopedi Nasional Indonesia. (2004). Ensiklopedi Nasional Indonesia Jilid 9. KL-LYSIT Cetakan Ke-4. Jakarta: PT Delta Pamungkas

Frankl, V.E.(1969). The Will to Meaning. New York: Plume book

Haloho, E., Rembang, M., \& Waleleng, Grace. (2016). Peran Media Sosial Terhadap Perilaku Pemilih Pemula pada Pemilihan Walikota dan Wakil Walikota Manado. Journal Acta Diurna, 5(3).

Kuswarno, Engkus. (2009). Metodologi Penelitian Komunikasi Fenomenologi Konsepsi, Pedoman, dan Contoh Penelitiannya. Bandung: Widya Padjajaran.

Limilia, P., \& Ariadne, E. (2018). Pengetahuan Dan Persepsi Politik Pada Remaja. Journal Psikologi Sosial. 16 (1).

Littlejohn, Stephen W., \& Karen A. Foss. (2009). Teori Komunikasi, edisi 9. Jakarta: Salemba Humanika

McQuail Denis. (1994). Teori Komunikasi Massa. Jakarta: Erlangga

Misiak, H., \& Sexton, V. (2005). Psikologi Fenomenologi, Eksistensial, dan Humanistik. Bandung: Refika Aditama

Moleong, Lexy J. (2007). Metodologi Penelitian Kualitatif. Bandung: PT Remaja Rosdakarya. Nurudin. (2013). Pengantar Komunikasi Massa. Jakarta: PT Raja Grafindo Persada

Pendit, P.L. (2003). Penelitian Ilmu Perpustakaan dan Informasi: Sebuah Pengantar Diskusi Epistemologi dan Metodologi. Depok: JIP-FSUI. 
Pirie, M. \& Worcester, R. (2000), The Big Turn-Off: Attitudes of Young people to Government, Citizenship and Community, London: Adam Smith Institute

Rakhmat, Jalaludin. (2012). Psikologi Komunikasi. Bandung: PT remaja rosdakarya.

Rozinah, Siti. (2012). Perilaku Pencarian informasi mahasiswa dalam penulisan skripsi,

Studi Kasus di Sekolah Tinggi Agama Islam Nahdlatul Ulama Jakarta. Depok: Fakultas Ilmu Budaya UI

Sandelowski, (1986). The Problem of Rigor in Qualitative Research. Journal of Science. 8(3). Sugiyono. (2013). Metodelogi Penelitian Kuantitatif, Kualitatif Dan R\&D. Bandung: Alfabeta Tamanna, M. (2018). The Political perception of youth: Where are we heading to?. Journal Akta. 5(5).

Undang-undang Republik Indonesia Nomor 42 tahun 2008 Tentang Pemilihan Umum Presiden dan Wakil Presiden. Yogyakarta: Pustaka Timur

Yustiningrum, R. R. Emilia., \& Ichwanuddin, Wawan. (2015). Partisipasi Politik dan Perilaku Memilih Pada Pemilu 2014. Journal Penelitian Politik. 12 (1).

\section{Electronic/Internet Source}

https://news.detik.com/berita/4215354/ada-5-juta-pemilih-pemula-di-pemilu-2019 diakses 10 Januari 2019 pukul 20.55 